\title{
Enhancing Job Satisfaction through Colleague Support and Communication
}

\author{
Andhy Tri Adriyanto ${ }^{1}$ \\ ${ }^{1}$ Doctoral Management Program of Sultan Agung Islamic University Semarang, Indonesia \\ ${ }^{*}$ Corresponding author.Email: andhy@usm.ac.id
}

\begin{abstract}
The influence of social support on job satisfaction Study still becomes polemic among researchers that trying to figure out how to increase job satisfaction through work engagement, social support, and quality communication. This research carried out in the Secretary office of the Semarang City Government 100 respondents were analyzed with PLS. Based on the data analysis result, social support has a significant effect on job satisfaction. However, social support did not significantly affect job involvement. The quality of communication has a significant effect on job satisfaction. The quality of communication is also a significant effect on job involvement. Work engagement has no significant effect on job satisfaction.

The weakness of this research is the original sample estimate of work engagement so it could not affect job satisfaction and the weak original sample estimate result of social support so it could not provide a significant effect on increasing the job involvement of workers. It was necessary to reexamine the empirical model on the relationship between social support and job involvement in the wider organization.
\end{abstract}

Keywords: Social Support, Quality of Communication, Job Involvement and Job Satisfaction.

\section{INTRODUCTION}

Governments that are directly dealing with broad community organizations are required to have human resources who are capable, skilled, dynamic, and always ready to serve the community. To become an organization that can serve the community excellently, it requires better human resources. Human resources have an important and very vital role because they are an asset of the organization to support organizational operations. As an asset, human resources must be maintained and developed, one of which is by increasing the job satisfaction of their human resources. Without the effort and contribution of human resources, an organization will not be able to meet the targets it has planned. Employees have different level of job satisfaction according to their value systems. when an employee meets the suitable earnings with their wishes, the higher the level of job satisfaction will get [1]. A scholar in his research argue that people will feel satisfied if there is no discrepancy between what they want and their perception of reality. [2] Employee attitudes and behaviour towards their work can affect the success of an organization to achieve its goals[3]. Antecedents in increasing job satisfaction are the quality of communication and good cooperation between human resources [4]. The quality of interpersonal communication is operationally defined as the level at which the content of the communication can be received and understood by other parties involved in the communication process [4]. It can be said that the best means of achieving quality is through communication between the service provider and the service recipient.

Interpersonal communication is a form of face-toface that has a feature where the effects and feedback, actions, and reactions are immediately visible because of the close physical distance of the participants [5]. Verbal, nonverbal, and reaction are immediately apparent. Therefore, face-to-face carried out continuously will be able to develop the quality of interpersonal communication that benefits both parties [6]. In the current research, researchers will focus more on the quality of human resources or the quality of interpersonal communication. A research entitled "Exploring the relationship between social support and job burnout among correctional staff" states that social support does not have a positive relationship with job satisfactionc[7]. Meanwhile, research conducted by the same but carried out at different research places and different respondents also research [8] "Social Support's Relationship To Correctional Staff Job Stress, Job Involvement, Job 
Satisfaction, And Organizational Commitment" shows that Social support has a significant positive effect on HR job satisfaction. Thus there is controversy over the results of research between social support and performance. Based on these conditions, this study tries to use the work involvement variable to resolve differences in the research findings of Lambert [8][7].

\section{LITERATURE REVIEW}

\section{Job Satisfaction}

Job satisfaction is a general attitude towards a person's job, which shows the difference between the amount of rewards employees receive and the amount they believe they should receive [1]. Job satisfaction described as a positive or negative attitude by individuals towards their work [9]. Job satisfaction is an attitude that workers have about their work and as a result of their perception of work [10]

Job satisfaction concluded as a pleasant or unpleasant emotional state experienced by an employee in connection with his job or with his condition. The indicators used are the work itself, the environment, and supervisory support [11].

\section{Social Support}

Social support is an exchange of assistance between two individuals who act as givers and recipients [12]. Colleague support is one of the social support given by organization and its described as an interpersonal exchange where an individual assists other individuals within organization [13]. Social support is comfort, attention, appreciation, or other forms of assistance that individuals receive from others or groups [14] Social support is an act that helps by involving emotions, providing information, material assistance, and positive assessments of individuals in dealing with their problems [15]. Colleague support is a positive feeling, liking, trust, and attention from others in the work life of the individual concerned, recognition, one's trust, and direct assistance in certain forms [16]. From those definitions, it can be concluded that social support is physical and psychological comfort, attention, appreciation, and assistance in the form of material, information, emotion, recognition, trust, which is received by individuals from other people or groups. The indicators used in this study are administrative support, peer support, and organizational support [17].

Colleague support affects job satisfaction. It shows that the higher the support of colleagues will increase one's job satisfaction [9], [18].

H1: $\quad$ The higher the social support, the higher one's job satisfaction will be.

Research on social support and work involvement has not widely obtained, so the references obtained are still very limited in the existing literature. The people supported by their colleagues in an organization will show better attitudes among others, will more involve with the work surround them[16] Colleague support can affects HR work involvement [18]. It shows that the higher the support from colleagues, the higher work involvement.

H2: $\quad$ The higher the social support, the higher the work involvement.

\section{Quality of Communication}

Organizational communication can be defined as the performance and interpretation of messages among communication units that are part of a particular organization [5]. An organization consists of communication units in hierarchical relationships between one another and functions in an environment [6]. Communication is the process of delivering a message by someone and another to inform or change attitudes, opinions, or behavior, either directly orally or indirectly through the media [4]. Communication can be concluded as a process of conveying messages by someone to change or shape the behavior of other people either verbally or through the media [19]. The communication effectiveness variable is operationalized and measured by indicators described in 4 items obtained from the [20] study include: ease of obtaining information, accuracy in providing information, willingness to provide information, and openness in providing information [6]. The results of research by [4], [19] concluded that the quality of communication has a significant effect on job satisfaction.

H3 The higher the quality of one's communication will increase job satisfaction.

The quality of communication can affects job involvement [18]. Employees in higher-quality exchange situations experience open communication with their supervisors. Effective interpersonal communication within organization is crucial as it is able to disseminate new ideas and share innovative development that benefits to increase job involvement [21]. So, it can be formulated that the better the quality of human resource communication will increase work involvement.

H4 The higher the quality of one's communication will increase work engagement.

\section{Work Involvement}

Work involvement refers to the extent to which a person identifies himself psychologically with his job, participates actively, and considers the level of HR performance he feels is important for self-esteem [16]. Job involvement is the level of identifying employees with their jobs, actively participating in their work, and 
considering the performance of their human resources in their work is more important for their good [22]. Work involvement as the degree to which individuals identify themselves with their work, actively participate in it, and consider their performance to be important for their selfesteemc [1].

It can be concluded that job involvement is the level at which an employee has a role in his job. An employee considers their job to be the most important thing in their life. The indicators used in this study are: actively participating in work, prioritizing work, and work is important for self-esteem [23]. Job involvement has an important role in increasing job satisfaction[24]. So that higher job involvement will increase HR job satisfaction. So that the proposed hypothesis is:

H5 The higher the work involvement, the higher the job satisfaction.

Social support is an action that helps by involving emotions, actively participating in organizational activities, providing information, material assistance, and positive assessments of individuals in dealing with their problems [9], [16]. Job involvement can be seen from the attitude of the individual in his thoughts about his job, where the individual considers that work is important for his self-esteem. Self-esteem is a combination of selfconfidence and self-respect, having strong self-esteem means feeling compatible with life and full of confidence, namely having the competence and being able to solve life's problems.

H6 Social support affects job satisfaction through job involvement

Antecedents in increasing job satisfaction are the quality of communication and good cooperation between human resources[4]-[6], [25]. Interpersonal communication is operationally defined as the level at which the content of the communication can be received and understood by other parties involved in the communication process. It can be said that the best means of achieving quality is through communication between the service provider and the service recipient.

H7 The quality of communication affects job satisfaction through job involvement

\section{Research Empirical Model}

From the literature review above, the empirical model constructs proposed in this study are :

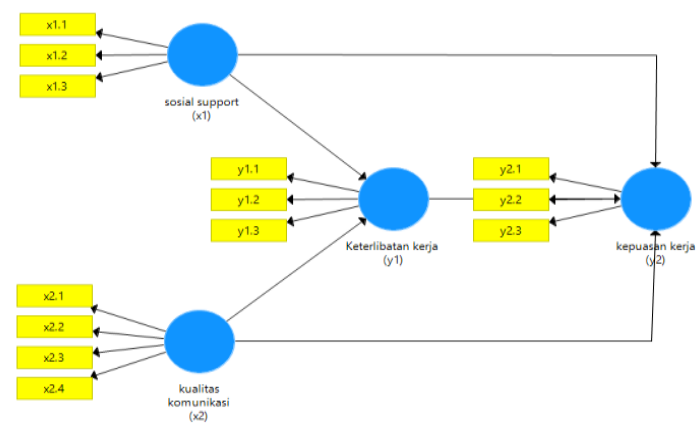

Figure 1. Empirical Model Constructions

\section{METHODS}

This research is explanatory research or research that is explaining, meaning that this research emphasizes the relationship between the research variables by testing the hypothesis, the description contains descriptions but the focus lies on the relationship between variables, namely social support, communication quality, job involvement, and job satisfaction. The population of the study was all 99 civil servants of the Semarang City Government Secretariat and rounded up to 100 respondents with the criteria of having a minimum service period of 2 years. The sampling technique used is incidental, namely, the technique of determining the sample based on chance, whoever accidentally / incidentally meets the researcher can be used as a sample if it is considered that the person who happened to be met is suitable as a data source. The analysis used to answer the hypothesis is structural equation modeling using the Partial Least Square (PLS) approach.

\section{Statistic analysis}

The reliability test is done by looking at the composite reliability value of the indicator block that measures the construct. The results of composite reliability will show a satisfactory value, if it is above 0.7 . Here is the composite reliability value for the output:

Table 1. Composite Reliability, AVE and R-Square

\begin{tabular}{|l|c|c|c|}
\hline & $\begin{array}{c}\text { Composite } \\
\text { Reliability }\end{array}$ & AVE & $\begin{array}{c}\text { R- } \\
\text { square }\end{array}$ \\
\hline Job Satisfaction & 0.841 & 0.643 & 0.591 \\
\hline Job Involvement & 0.800 & 0.573 & 0.454 \\
\hline $\begin{array}{l}\text { Quality of } \\
\text { Communication }\end{array}$ & 0.838 & 0.633 & \\
\hline Social support & 0.780 & 0.545 & \\
\hline
\end{tabular}

Table 1 above shows that the composite reliability value for all constructs is above 0.7 indicates that all the constructs in the estimated model meet the criteria for discriminant validity. To strengthen the reliability test, the test was carried out with the Average Variance Extracted (AVE) value, if the AVE value was $>0.5$ then 
the indicators used in the research were reliable, and could be used for research. Table 1 shows the results of the Average Variance Extracted (AVE) of each construct are good, which is above 0.5 , which means it has a good reliability value and can be used for further research processes. The table above gives a value of 0.591 for the construct of job satisfaction and it means that social support, quality of communication, and job involvement can explain the variance of job satisfaction by $59.1 \%$, the remaining $40.9 \%$ is explained by other variations that are not included in the model. The value of $\mathrm{R}$ is also found in work involvement which is influenced by social support and communication quality, namely $45.4 \%$, the remaining $54.6 \%$ is influenced by other variables that are not included in the model. Hypothesis testing is as follows:

Table 2. Hypothesis Testing

\begin{tabular}{|l|l|l|l|l|l|}
\hline & $\begin{array}{l}\text { Original } \\
\text { Sample } \\
\text { (O) }\end{array}$ & $\begin{array}{l}\text { Sample } \\
\text { Mean } \\
\text { (M) }\end{array}$ & $\begin{array}{l}\text { Standard } \\
\text { Deviation } \\
\text { (STDEV) }\end{array}$ & $\begin{array}{l}\text { T Statistics } \\
(\mid \mathrm{O} / \mathrm{STDE} \\
\mathrm{V} \mid)\end{array}$ & P Values \\
\hline $\begin{array}{l}\text { Job } \\
\text { Involvement } \\
\text { (y1) -> Job } \\
\text { Satisfaction_ } \\
\text { (y2) }\end{array}$ & 0.231 & 0.166 & 0.111 & 1.354 & 0.234 \\
\hline $\begin{array}{l}\text { Quality of } \\
\text { Communicati } \\
\text { on_(x2) -> } \\
\text { Job } \\
\text { Involvement } \\
\text { (y1) }\end{array}$ & 0.677 & 0.432 & 0.077 & 7,233 & 0.000 \\
\hline $\begin{array}{l}\text { Quality of } \\
\text { Communicati } \\
\text { on_(x2) -> } \\
\text { Job } \\
\text { Satisfaction_ } \\
\text { (y2) }\end{array}$ & 0.222 & 0.318 & 0.099 & 3,988 & 0.000 \\
\hline $\begin{array}{l}\text { sosial } \\
\text { support_(x1) } \\
-> \\
\text { Involvement } \\
\text { (y1) }\end{array}$ & 0.162 & 0.211 & 0.118 & 1.813 & 0.077 \\
\hline $\begin{array}{l}\text { Sasial } \\
\text { support_(x1) }\end{array}$ & 0.777 & 0.203 & 5,368 & \\
\hline
\end{tabular}

The table above shows that the original sample value estimates of social support and work involvement are 0.162 which indicates that the direction of the relationship between social support and work involvement is positive. The relationship between social support and job involvement was not significant with a
T-statistic of $1.813<1.99$. Thus, the $\mathrm{H} 1$ hypothesis in this study states that 'social support influences job involvement is rejected.

The table above shows the original sample estimate value between social support and satisfaction of 0.605 which indicates that the direction of the relationship between social support and satisfaction is positive. The T-statistic value is $5,368 \mathrm{c}>1.99$, so it is stated to have a significant relationship. Thus the $\mathrm{H} 2$ hypothesis in this study which states that social support affects employee performance is accepted.

The table above shows that the T-statistic value of the relationship between communication quality and work involvement is $7.233>1.99$ and the original sample estimate value is 0.677 which indicates that the direction of the relationship between communication quality and work involvement is positive. Thus the hypothesis $\mathrm{H} 3$ in this study which states that the quality of communication affects work involvement is accepted.

The table above shows that the relationship between communication quality and satisfaction is significant with a T-statistic of $3.988>1.99$. The original sample estimate value is positive, as big as 0.222 which indicates that the direction of the relationship between communication quality and performance is positive. Thus the hypothesis H4 in this study which states that the quality of communication affects performance is accepted.

The original sample value estimate of work involvement and satisfaction is 0.231 indicates that the direction of the relationship between work involvement and satisfaction is positive. The table above shows that the relationship between job involvement and satisfaction has a T-statistic value of $1.354<1.99$. Thus the hypothesis H5 in this study states that job involvement affects employee satisfaction is accepted.

Based on the original sample estimate value, it found that the highest value that affects work involvement is the quality of communication, which is 0.571 . It shows that the quality of communication has a higher influence on work involvement than the influence of social support. Furthermore, of the three variables that directly affect HR job satisfaction, namely social support, quality of communication, and work involvement, the one with the greatest influence is social support because it has the highest original sample estimate value of 0.504 compared to the other two variables. Thus social support is the most dominant variable in influencing HR job satisfaction. Meanwhile, the least dominant variable was work engagement, namely the smallest original sample estimate of 0.146 . 


\section{RESULTS AND DISCUSSION}

Figures and tables should be placed either at the top or Social support has a significant effect on job satisfaction. It means that the more a person gets high social support, the higher his job satisfaction. This social support can come from different sources, such as a spouse or loved one, family, friends, co-workers, or members of an organization. With social support from various sources, individuals will feel confident that they are loved and cherished, valued, valued, and become part of the social network in their work environment. Social support refers to comfort, care, self-esteem, or all forms of assistance that individuals receive from other people or groups. In the world of work, a person is faced with a work situation that is full of demands and pressure. High job demands will cause many problems for individuals and can hurt one's work performance if it is not balanced with the support provided by the organization. HR perceptions of social support provided by colleagues, ease of administrative management, and support provided by organizations will increase HR satisfaction with the work itself, more satisfied with physical and non-physical environmental conditions, and satisfied with supervisory support carried out by superiors

Social support does not have a significant effect on worker involvement. This indicates that although the perception of HR towards social support provided by colleagues is very good, it is not able to make HR more actively participate in work, the ease of administrative management obtained by HR is not able to encourage HR to actively participate in work and prioritize work, and although support given the very high organization is unable to increase the meaning of work for self-esteem. This study contradicts the results of research by [22] which states that peer support affects HR work involvement. Social support does not only have a positive effect on influencing the incidence of anxiety effects. Some examples of the negative effects arising from social support in the daily life of human resources in the Semarang City Government Secretariat include: the support provided was not considered helpful. This can occur because the support provided is not enough, individuals feel they do not need help or are too worried emotionally so they do not pay attention to the support provided. The second is when the support provided does not match what the individual needs. The next effect is that the source of support gives bad examples to individuals such as doing or suggesting unhealthy behavior so that the human resources who are given support feel embarrassed and worried about the social judgments made by other colleagues, which are considered as bad as the support provider. The final effect is to protect or not support the individual in doing something he wants. The social support received by HR makes HR unable to work independently and always depends on the help of others. This situation can interfere with the rehabilitation program that should be carried out by individuals and cause individuals to become dependent on others so that the involvement of human resources is reduced.

The quality of communication has a significant effect on job satisfaction. It means that the higher the quality of communication that exists in the organization, the higher the job satisfaction of its human resources will be. The quality of communication has a significant effect on worker involvement. ob involvement does not have a significant effect on job satisfaction. It means that the more human resources involved in organizational activities will not affect their HR job satisfaction. Employees with a high level of work involvement recognize and pay attention to the work they do but it does not affect HR satisfaction with their work, highinvolvement HR will actively participate in their work but this does not increase HR satisfaction with the physical and non-physical environment in the Regional Secretariat of the Semarang City Government. HR with high involvement always considers the performance of their human resources in their work as important for their good, but this does not increase satisfaction with supervisory support from their superiors. On the other hand, employees whose job satisfaction is low tend to see work as tedious and boring, so they work forced and carelessly.

The conclusion is that job involvement cant be the driving factors for $\mathrm{HR}$ job satisfaction, it can be compared to the satisfaction level of new employees and old employees in the organization. New human resources tend to have a higher level of satisfaction than those with longer tenure. It is because new human resources get more attention from organizations, especially from their direct superiors. Meanwhile, old employees who have worked for a certain period will feel boredom. They want changes and new challenges in their work. This challenge encompasses both the size of the responsibility or perhaps the type of work. When companies do not provide opportunities for them to develop, this will make them demotivated, lazy to work, and their productivity decreases. Each individual has a different level of job satisfaction according to the value system that applies to him. HR satisfaction from one another is different. High job involvement does not necessarily increase HR job satisfaction if it is associated with an increase in income obtained from job involvement. HR in the Regional Secretariat of the Semarang City Government has high expectations of the incentives that may be given when involved in organizational activities. So when HR does not get what they want from their involvement, HR feels that their job satisfaction is not being met. 


\section{CONCLUSION}

\section{Conclusion}

Based on hypothesis testing, social support has a significant effect on job satisfaction. However, social support does not have a significant effect on job involvement. The quality of communication has a significant effect on job satisfaction. The quality of communication also has a significant effect on job involvement. Job involvement does not have a significant effect on job satisfaction.

\section{Managerial Implications}

To increase employee satisfaction in the Regional Secretariat of the Semarang City Government, it is necessary to improve the quality of communication, social support, and work involvement. Thus the quality of communication can be improved through the behavior of sharing information. The loading of the factor accuracy of providing information is the highest indicator of the variable quality of communication. It means that organizations must often hold discussion forums so that information exchange behavior can run optimally.

In connection with the work involvement of the organization, it must increase the value of planting that existing work is important for current HR. It can be done through regular mental and spiritual guidance for human resources. The loading factor of active participation in work is the highest indicator of job involvement variables. It means that the organization must increase the participation of its human resources in every activity of the organization.

In increasing HR perceptions of received social support, organizational support is the highest indicator of social support variables. This means that the organization must increase organizational support for its social HR needs. based on the findings obtained that the organization must increase the support of colleagues in carrying out the completion of HR tasks. This can be done by conducting regular teamwork building activities.

To increase HR job satisfaction, job satisfaction itself gets the lowest score, meaning that the organization must further instill job prestige in its human resources by increasing organizational performance so that the human resources in it feel proud and satisfied to be part of the organization. The highest loading factor for the job satisfaction variable is satisfaction with the supervisor's supervision. So that the organization must improve the supervisory function / supervisory supervisor on HR performance.

\section{Research limitations}

Based on the results of research and discussion, it can be seen that the weakness of this study is the result of the original sample of estimated low job involvement so that it is unable to increase job satisfaction. And the original sample of estimated social support is low so that it is unable to have a significant effect on increasing work involvement.

\section{Upcoming Research Agenda}

The R Square value for low job involvement is only $46.5 \%$, so there are still $53.5 \%$ supporting factors for other job involvement that are not included in the model. So it is necessary to conduct further research on the causal relationship between social support and work involvement in other larger organizations.

\section{REFERENCES}

[1] J. Ćulibrk, M. Delić, S. Mitrović, and D. Ćulibrk, "Job satisfaction, organizational commitment and job involvement: The mediating role of job involvement," Front. Psychol., vol. 9, no. FEB, pp. 1-12, 2018, doi: 10.3389/fpsyg.2018.00132.

[2] A. Khan, J. Stanton, and S. Rahman, "Employees' attitudes towards the sponsorship activity of their employer and links to their organisational citizenship behaviours," Int. J. Sport. Mark. Spons., vol. 14 , no. 4, pp. 20-41, 2013, doi: $10.1108 /$ ijsms14-04-2013-b003.

[3] I. Valor-Segura et al., "Predicting Job Satisfaction in Military Organizations: Unpacking the Relationship Between Emotional Intelligence, Teamwork Communication, and Job Attitudes in Spanish Military Cadets," Front. Psychol., vol. 11, no. May, pp. 1-9, 2020, doi: 10.3389/fpsyg.2020.00875.

[4] J. J. Obiunu, "Influence of Emotional Intelligence, Interpersonal Communication and Job Satisfaction on the Job Performance of Staff in Chevron Nigeria Limited, Warri, Delta State Nigeria," pp. 160-167, 2020.

[5] R. A. Snyder and J. H. Morris, "Organizational communication and performance," $J$. Appl. Psychol., vol. 69, no. 3, pp. 461-465, 1984, doi: 10.1037/0021-9010.69.3.461.

[6] K. M. Nyandongo and M. Davids, "The impact of communication on project performance: An empirical study," 26th Int. Assoc. Manag. Technol. Conf. IAMOT 2017, pp. 404-425, 2020.

[7] E. G. Lambert, "The relationship of organizational citizenship behavior with job satisfaction, turnover intent, life satisfaction, and burnout among correctional staff," Crim. Justice Stud., vol. 23, no. 4, pp. $361-380, \quad 2010, \quad$ doi: $10.1080 / 1478601$ X.2010.516533. 
[8] E. G. Lambert, K. I. Minor, J. B. Wells, and N. L. Hogan, "Social support's relationship to correctional staff job stress, job involvement, job satisfaction, and organizational commitment," Soc. Sci. J., vol. 53, no. 1, pp. 22-32, 2016, doi: 10.1016/j.soscij.2015.10.001.

[9] Z. Jiang and X. Hu, "Knowledge Sharing and Life Satisfaction: The Roles of Colleague Relationships and Gender," Soc. Indic. Res., vol. 126, no. 1, pp. 379-394, 2016, doi: 10.1007/s11205-015-0886-9.

[10] M. Cortini, D. Converso, T. Galanti, T. Di Fiore, A. Di Domenico, and S. Fantinelli, "Gratitude at work works! A mix-method study on different dimensions of gratitude, job satisfaction, and job performance," Sustain., vol. 11, no. 14, 2019, doi: 10.3390/su11143902.

[11] B. E. Alown, M. Mohamad, and F. Karim, "Structural Equation Modeling Based Empirical Analysis: Direct and Indirect Effects of Job Satisfaction on Job Performance in Jordanian FiveStar Hotels," J. Tour. Hosp. Environ. Manag., vol. 5, no. 18, pp. 133-151, 2020, doi: 10.35631/jthem.5180012.

[12] A. Rimmer, "How can i support a colleague who is being investigated?," BMJ, vol. 367, no. November, pp. 10-11, 2019, doi: 10.1136/bmj.16426.

[13] M. S. Birkeland, M. B. Nielsen, M. B. Hansen, S. Knardahl, and T. Heir, "Like a bridge over troubled water? A longitudinal study of general social support, colleague support, and leader support as recovery factors after a traumatic event," Eur. J. Psychotraumatol., vol. 8, no. 1, 2017, doi: 10.1080/20008198.2017.1302692.

[14] Y. Chen, "Can Supervisor Support Mitigate the Impact of Colleague Exclusion on Silence Behavior?-A Moderated Mediating Model," Open J. Soc. Sci., vol. 06, no. 10, pp. 132-145, 2018, doi: 10.4236/jss.2018.610011.

[15] E. Kleszewski and K. Otto, "The perfect colleague? Multidimensional perfectionism and indicators of social disconnection in the workplace," Pers. Individ. Dif., vol. 162, 2020, doi: 10.1016/j.paid.2020.110016.

[16] M. Vassos, K. Nankervis, T. Skerry, and K. Lante, "Can the job demand-control-(support) model predict disability support worker burnout and work engagement?," J. Intellect. Dev. Disabil., vol. 44, no. 2, pp. 139-149, 2019, doi: 10.3109/13668250.2017.1310818.

[17] E. G. Lambert, L. D. Keena, M. Leone, D. May, and S. H. Haynes, "The effects of distributive and procedural justice on job satisfaction and organizational commitment of correctional staff," Soc. Sci. J., 2019, doi: 10.1016/j.soscij.2019.02.002.

[18] R. Pratiwi, "Fostering Job Satisfaction: The Role of Communication Quality and Colleague Support in Job Involvement," AKSES J. Ekon. dan Bisnis, vol. 14, no. 2, pp. 66-70, 2020, doi: 10.31942/akses.v14i2.3270.

[19] I. Sualman, F. H. A. Razak, M. I. S. Hamzah, and Y. Darwis, "The level of organizational communication satisfaction and job satisfaction of global customer fulfilment workers," Glob. Compet. Bus. Transform. Digit. Era, pp. 276-279, 2019, doi: 10.1201/9780429202629-50.

[20] N. Sharma and P. G. Patterson, “101108_08876049910266059," vol. 13, no. 2, pp. $151-170,1999$.

[21] C. Sriviboon and K. Jermsittiparsert, "Influence of human resource practices on Thai pharmaceutical firm performance with moderating role of job involvement," Syst. Rev. Pharm., vol. 10, no. 2, pp. 234-243, 2019, doi: 10.5530/srp.2019.2.32.

[22] A. Bahjat Abdallah, B. Yousef Obeidat, N. Osama Aqqad, M. N. Khalil Al Janini, and S. E. Dahiyat, "An Integrated Model of Job Involvement, Job Satisfaction and Organizational Commitment: A Structural Analysis in Jordan's Banking Sector," Commun. Netw., vol. 09, no. 01, pp. 28-53, 2017, doi: $10.4236 / \mathrm{cn} .2017 .91002$.

[23] D. Varshney, "Employees' job involvement and satisfaction in a learning organization: A study in India's manufacturing sector," Glob. Bus. Organ. Excell., vol. 39, no. 2, pp. 51-61, 2020, doi: 10.1002/joe. 21983.

[24] L. M. Al Basyir, R. Madhakomala, and A. W. Handaru, "The effect of transformational leadership, organizational communication and job involvement toward withdrawal behavior," Manag. Sci. Lett., vol. 10, no. 7, pp. 1623-1632, 2020, doi: 10.5267/j.msl.2019.12.004.

[25] J. Eisenberg, C. Post, and N. DiTomaso, "Team Dispersion and Performance: The Role of Team Communication and Transformational Leadership," Small Gr. Res., vol. 50, no. 3, pp. 348-380, 2019, doi: $10.1177 / 1046496419827376$. 